\title{
Supervisor Trust and Counterproductive Work Behaviour of Oil Firms in Port Harcourt - Nigeria
}

\author{
Dr Omoankhanlen Joseph Akhigbe ${ }^{1}$, Sonye, Lillian Amamino ${ }^{2}$ \\ ${ }^{1}$ Senior Lecturer Department Of Management Faculty Of Management Sciences University Of Port Harcourt \\ Rivers State - Nigeria \\ ${ }^{2}$ Department Of Management Faculty Of Management Sciences University Of Port Harcourt
}

\begin{abstract}
This study examined the relationship between supervisor trust and counterproductive work behaviour of oil firms in Port Harcourt. Trust has been known to play a vital role in organizations but lack of supervisor integrity has led subordinates into engaging themselves in counterproductive work behaviours. Counterproductive work behaviour has increased a great cost to both the organisation and the employees. A cross sectional survey consisting 278 employees drawn from three oil firms in Port Harcourt. Data used in this study were obtained from the primary and secondary sources. Spearman's rank order coefficient correlation was used for analysis with the aid of SPSS version 21.0. The findings revealed that there is a positive link between the dimension of supervisor trust and the measures of counterproductive work behaviour. Another finding revealed that corporate culture has a strong moderating effect on the relationship between supervisor trust and counterproductive work behaviour. Hence, supervisor trust has a positive impact on counterproductive work behaviour and that corporate culture has a strong moderating factor to influence the relationship between supervisor trust and counterproductive work behaviour. Management of oil firms should practice and encourage their supervisors/ managers to have integrity in order to reduce their rate of personal aggression behaviour (verbal abuse, sexual abuse, etc). This has a way of boosting the image of the company. Recommendations were given one of which is that corporate culture should be highly encouraged in the oil firms in Port Harcourt.
\end{abstract}

Keynote: Supervisor Trust, Counterproductive Work Behaviour, Supervisor Integrity, property deviance, Personal Aggression, corporate culture

\section{Introduction}

Oil firms generally have the objective of developing relationship with clients, seek for most reliable, honest and skilled workforce in order to achieve a higher level of increase and at the same time maximize profit, in a bid to achieve their objectives and maintain their values, superior and subordinate relationship is highly encouraged (Mcknight \& Chervany,1996; Shell International Limited, 2014; Wikipedia,2017).

Despite the fact that there are a few sorts of trust however this study will make use of interpersonal trust since it is fixated on leader/follower relationship. Trust has been observed to be of incredible significance. It is a critical instrument that assists the progress of an organization. McKnight \& Chervany, (1996) in Maanen (2014) state that since capacity, kindness and honesty of trustee covers most characteristics of trust, they ought to hence be utilized to depict and measure trust. Savolainen, Hakkinen \& Powell (2011) declares that trust is the motivation behind why we have compelling administration. It shapes the establishment whereupon connections and co-operation between the boss and subordinate is manufactured (Costa, \& Bijlsmafrankema, 2007) in Findikli, Gulden \& Semercioz (2010). Trust additionally impacts hierarchical procedures, for example, correspondence, co-operation and data sharing which constantly influences an association's profitability (Savolainen, Hakkinen \& Powell, 2011; Mayer \& Davis, 1999).

A few analysts additionally showed that trust is an issue solver, and it brings participation among representatives, along these lines, making them play out their assignment viably (Zand, 1992; Axelrod, 1994; Mayer, \& Davis, 1999). On the off chance that trust is viewed as an issue solver, it then implies that counterproductive work conduct (CWB) can be decreased or destroyed when trust is permitted to take its cause between the subordinate and the superior. It is frequently said that representatives that trust their superior work adequately and are focused on their employment, (Savolainen, Hakkinen \& Powell (2011). Trust is the hope that some individual has on another with the desire that the other individual will play out a specific activity that is imperative to him whether he screens him or not (Mayer, Davis \& Schoorman, 1995).

Counterproductive work behaviour (CWB) is a deliberate conduct that employees carryout in the working environment that conflicts with the authoritative standards and furthermore debilitates the presence of the association and its representatives (Robinson \& Bennett (1995). Mangione \& Quinn (1975) named it Counterproductive conduct. Hostile to social conduct is likewise seen as unscrupulous conduct in the working environment as expressed by Giacalone \& Greenberg (1997). Bennett \& Robinson (2003) called it deviant conduct; Robbins \& Judge (2007) likewise distinguished it as work environment incivility. All these demonstrate that diverse Scholars had seen the exploitative practices and have given it names in light of how they comprehended it. They all bear witness to the way that the conduct is deliberately done in the work environment (Kabiru, Faridahwati \& Ajay, 2013 in Paul, 2015; Robinson \& Bennett, 1995; Bennett \& Robinson, 2003). 
At the point when a supervisor needs capacity, (aptitudes, skill, and so on); generosity, (mindful, goodwill, accommodating, and so on); and respectability (genuineness, equity, and so forth), subordinates won't confide in their pioneers. Absence of Trust in a Supervisor can lead to a negative desire demonstrating dread in the psyche of both sides, that the other may not take care of his prosperity and may bring about him hurt (Lewicki, 2006; Gillespie \& Dietz, 2009). Doubt has the ability to break business connection and impact work demeanor (Dirks \& Ferrin, 2002) in Maanen (2014).

\section{Problem Statement}

When a supervisor lacks integrity (honesty, justice, etc), subordinates do not trust their leader (Lewicki, 2006). Lack of Trust in a Supervisor leads to a negative expectation indicating fear in the mind of both parties, thus making subordinate engage themselves in counterproductive work behaviours (Lewicki, 2006; Bennett \& Robinson, 2000; Gillespie \& Dietz, 2009).

Counterproductive work conduct has expanded an incredible cost on the organisation and its representatives based on the losses made. The misfortunes in the part of the organization comes in the aspect of property aberrance and individual hostility practices (disrupting organization gear, lying about hours worked, taking from the organisation, taking inordinate breaks, delay to work, and so forth). The impact on the workers that is, individual hostility (inappropriate behavior, verbal mishandle, jeopardizing associates, taking from colleagues, et cetera), is additionally high since it influences the worker adversely (Robinson \& Bennett 1995; Bennett \& Robinson, 2000).

Evidence from Nigerian oil firms shows that some supervisors have no trust in their subordinate and vice versa. Therefore, this study shall seek to know how trust in supervisor integrity can influence property deviance and personal aggression behaviours of oil firms in Port Harcourt.

\section{Research Gap}

Despite all the scholarly works done on supervisor trust, much exertion have not been done to tackle counterproductive work conduct in respects to the oil firms in Port Harcourt, this has created a literature gap, to this end therefore, this study shall fill the gap by examining the connection between the supervisor trust and counterproductive work behaviour of oil firms in Port Harcourt.

\section{Operational Framework}

Fig.1: The study operational framework

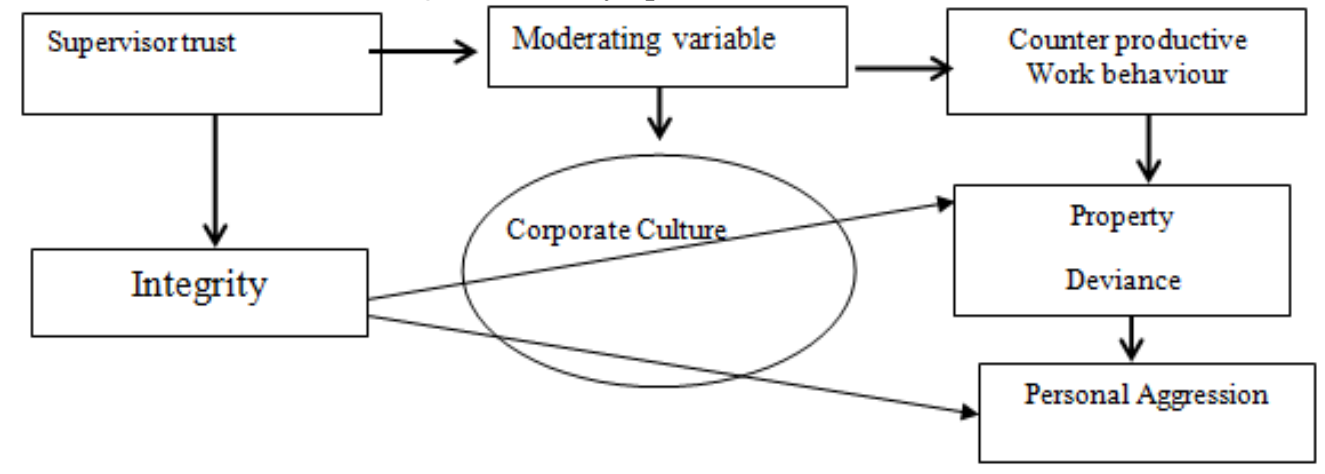

\section{Source: Conceptualised by Researchers, 2017}

The operational framework focused on two measures of the dependent variable adapted from Robinson \& Bennett, (1995). One dimension of the independent variable followed the works of Mayer, Davis \& Schoorman (1995); while the Moderating variable is the Corporate Culture.

\section{Objective of the Study}

The study specific objectives are:

1. To establish the relationship between Supervisor Integrity and property deviance of oil firms in Port Harcourt.

2. To establish the relationship between Supervisor Integrity and Personal Aggression of oil firms in Port Harcourt.

3. To ascertain if corporate culture will moderate the relationship between Supervisor Trust and counterproductive work behaviour (CWB) of oil firms in Port Harcourt.

\section{Research Hypotheses}

The study hypotheses were hypothesized as follows: 
Ho1: There is no significant relationship between Supervisor Integrity and Property deviance behaviour of oil firms in Port Harcourt.

H02: There is no significant relationship between Supervisor Integrity and Personal Aggression behaviour of oil firms in Port Harcourt.

Ho3: Corporate Culture will not moderate the relationship between Supervisor Trust and Counterproductive Work behaviour of oil firms in Port Harcourt.

\section{Literature Review}

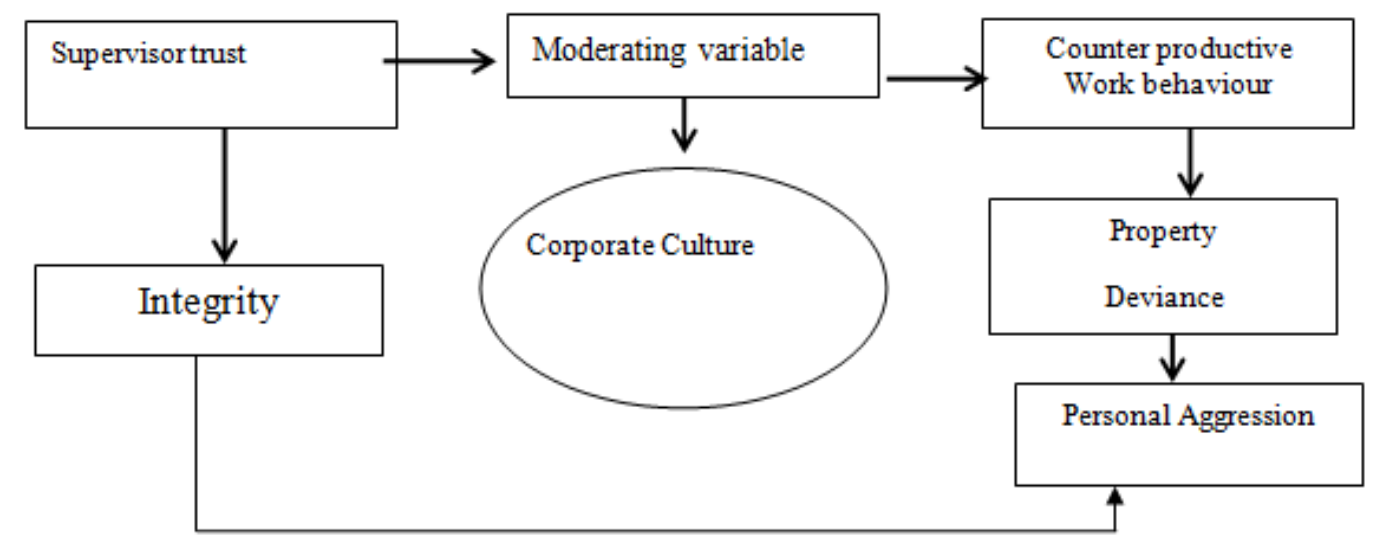

\section{Source: Conceptualized by Researchers, 2017}

The conceptual framework focused on two measures of the dependent variable adapted from Robinson \& Bennett, (1995). One dimension of the independent variable followed the works of Mayer, Davis \& Schoorman (1995); while the Moderating variable is the Corporate Culture.

\section{* Theoretical Framework}

The prominence of trust has driven numerous researchers into inquiring about it, in this manner, researchers sought and thought of theories like the leader-member exchange theory (LMX), which is the degree to which a subordinate feels that he has a place with the manager in-gathering and along these lines the nature of their connection will be ensured (Gomez \& Rozen, 2001). Trust could be viewed as a critical element that can compel a representative to play out his occupation adequately (Conway, 2011) and taking a gander at the examination take a shot at trust in director, one will reason that the LME has had an awesome effect in connection amongst worker and his prompt administrator which has likewise prompted increment in the worker work execution (Conway, 2011). LMX theory certify to the way that those worker that are individuals from the supervisor's in-gathering have a tendency to have great trade that prompts increment in organization profitability which will make employees to assume additional parts and carry on decidedly Danserean, Graen, \& Haga, 1975; Gerstner and Day, 1997, Iies, Nahrgang, \& Morgeson, 2007).

\section{- Dimension of Supervisor Trust}

Dimension of supervisor trust used for this study is integrity which was taken from the works of Mayer, Davis \& Schoorman, (1995).

\section{- Supervisor Integrity}

Integrity is one of the criteria of trust value. As indicated by Mayer, Davis \& Schoorman (1995), notwithstanding capacity and consideration, they stated that bosses must have trustworthiness which is detectable by the subordinate, since the standard of an administrator is watched frequently by his subjects. This is known with the way he connects with his associates and subordinate. Mayer, Davis \& Schoorman (1995) states that uprightness is the esteem a worker has which is satisfying to the business. It is accordingly sure that for anybody to be a pioneer he should have values that will attract the subordinate to him. Furthermore, in another way we can likewise say that, for an association to hold a representative, that worker must have a few qualities which are helpful to the business. Respectability implies acting as indicated by adequate and ethnic standards e.g. Reasonableness, trustworthiness, and so forth (Thompson, 2012). Mayer, Davis \& Schoorman (1995) depicted respectability as the route in which one gathering watches that the other party is carrying on in the way that is satisfactory to him. The equivalent words of respectability as sketched out by (Colquitt, Scott \& LePine, 2007) are: - reasonableness, equity, consistency, and guarantee satisfaction. A man can be seen as being more noteworthy when he can keep his words, this is the reason Tan \& Lim (2009) said that trust is appraised 
higher in associates when they are seen as more decent in light of the fact that the final product of their activities and conduct swings up to be that they are reliable, legitimate and just in their judgment, thus pioneers/managers are along these lines ordered to be respectable so that the supporters (subordinate) will lessen or maintain a strategic distance from any demonstration of counterproductive work conduct they have been doing (Burke, Sims, Lazzara \& Salas, 2007).

\section{* Consequences of Supervisor Trust on Organisation}

Trust is the hope or belief someone has on another person, with the hope that the person can perform a particular task. Supervisor trust therefore is the belief a subordinate has on the superior based on his ability to perform a task with a higher skill and competence. The consequence of supervisor trust can be viewed in the positive/negative impact it creates in the organization in the following ways:

\section{- Commitment}

Savolainen, Hakkinen \& Powell (2011) viewed trust employee had on their leaders as a tool that increases effective performance of task and also increases the employee rate of commitment. This is because the subordinate had observed the supervisor abilities, benevolence and integrity and had found him to be more knowledgeable and skilled.

\section{- $\quad$ Relationship Building}

Trust have been found to possess such capability to influence the organization processes by building the link between the supervisor and subordinate through communication and cooperation as the supervisor becomes more skilled and show the subordinate some level of benevolence. When link is well built, the subordinate trust in their supervisor increases which will affect his work attitude positively.

\section{- Job Performance}

When a subordinate trust his/her supervisor, it increases the work performance and give room for positive deviant behaviour which builds the link and increases employee desire to stay in the job (Colquitt, Scott, \& LePine, (2007).

\section{- Measures of Counterproductive Work Behaviours \\ - Property Deviance}

Property deviance follows workers purposeful conduct to procure or harm a firm's equipment in the workplace without an authorisation; this conduct hurts the association and can set it in reverse (Robinson \& Bennett 1995). These practices incorporate; sabotage, tolerating kickbacks, lying for quite a long time worked, taking from the organization (illicit taking of organization's property, theft of store, and so forth). These practices are unsafe to the association and it is a genuine one on the grounds that the organization can't advance without a replacement.

\section{- Personal Aggression}

Personal aggression as a type of counterproductive work conduct is a negative conduct which representative's carryout in the workplace which works specifically against the worker prosperity in the working environment (Robinson \& Bennett 1995; Bennett \& Robinson 2000). It is a conduct that runs with hostility against associates. It can come in various ways like: verbal misuse, lascivious behavior, assault, physical strike, and so forth. This conduct can influence the subordinate feeling and his physical wellbeing conditions.

\section{- Consequences of Counterproductive work behaviour on organisations.}

Counterproductive work behaviour is an employee unethical behaviour carried out purposefully in the work place which has the capacity of threatening the existence of both the organization and its employee. The consequences of counterproductive work behaviour are explained below.

\section{- $\quad$ Fraud/Embezzlement of Fund}

When an employee deceives another in order to get money that does not legally belong to him, it is fraud. Taking kickback, lying about hours worked in order to receive pay for overtime, misusing the expense account, etc are all act of fraud which does not allow an organization to grow as well as compete favourably with the competitors (Robinson \& Bennett (1995).

\section{- Sabotage}

Sabotage has to do with a purposeful destruction of company's equipment by an employee. So, instead of an organization to continue in using the equipment for production, they end up replacing the equipment or repairing it. This is a real cost to the organization (Robinson \& Bennett,1995; Peterson, (2002). Sabotage of equipment in the oil companies has resulted into spills, discharges \& explosions both accidental \& operational, thus affecting communities and lives of the public, Nwankwo \& Irechukwu, (1981); Nwankwo \& Ifeadi (1988). They also asserted that the accidental spills are attributed to lubrication of oil during transportation, storage, 
marketing and utilization of petroleum product. It was Sabotage that led to the close down of Port Harcourt and Warri plant in 2015 (premium times 2015).

\section{- Verbal Abuse/Bullying}

When a superior abuses or bully on the subordinate at every little mistakes in the workplace, it affects the employee emotions, which will also affect the rate of productivity and cause the employee to purposefully perform any task wrongly or even destroy company equipment to increase a financial cost on the company (Cocck 1998); Covey \& Conant (2016).

\section{- Sexual Harassment /Abuse}

According to Zunda, (1998), sexual harassment /abuse brings down the quality or value of a person. It affects the attitude of a manager /supervisor to work, in that, a manager may not be bold to take the right disciplinary measure on such employee he has sexually abuse which will worsen the situation in the workplace as every other one will toe the footprint of the defaulter. Such action will affect the job Performance and destroy the company's image.

\section{* Empirical Studies Review}

A number of research studies were carried out to determine the level at which supervisor trust can reduce counterproductive work behaviour in an organization, some of the reviewers are mentioned below;

Likewise, in Obio/Akpo in Rivers State, Hart (2015) completed a review on trust in chief and authoritative citizenship conduct in 97 private healing facilities with around 181 representatives in the zone. The review gone for exploring, the connection between trust in manager and authoritative citizenship conduct. The outcome demonstrated that positive connection exist between trust in chief and hierarchical citizenship conduct which suggests that trust in administrator upgrades authoritative citizenship conduct.

In Nigeria, Paul (2015) done a review on degenerate conduct and firm development in assembling firms in Port Harcourt. A specimen size of 224 workers was utilized for the review in 7 chose fabricating firms in Port Harcourt in Rivers State. The outcome uncovered that degenerate conduct has a positive and noteworthy connection with firm development.

Findikli, Gulden \& Semercioz (2010) led a review on subordinate trust in director and association: Effects on subordinate impression of brain research strengthening. The review test estimate comprises of 112 workforces in 3 firms managing barrenness treatment in pharmaceutical industry and providing hormones for follicular advancement. The outcome demonstrated that there is no huge distinction as far as statistic calculates the part of trust in chief and there was a huge contrast in the part of sexual orientation and training given to the way that a solid and positive connection exist between trust in director and the subordinate impression of brain science strengthening.

\section{Methodology}

Research Design adopted in this study is cross-sectional survey which is an aspect of the quasiexperimental research design. The target population of this study consists of the line and contract staff of three oil firms in Port Harcourt, while the accessible population was 1000 employees drawn from 76 departments of three oil firms in Port Harcourt. The sampling technique used for this study was simple random sampling technique, (Etikan, Musa \& Alkassim, (2016).

\section{* Sampling Size Determination}

In determining the sample size, Krejcie \& Morgan (1970) table was used and on the table a population of 1000 gave a sample size of 278 (see appendix 1)

\section{* Methods of Data Analysis}

In order to present the findings in a concise pattern, the researcher employed the descriptive statistics which involves percentages and tables in order to properly organise the data. In a bid to test the hypotheses for accuracy, the researcher made used of the Spearman's rank order coefficient correlation in order to support the answers obtained from the ordinal data collected from the field. The formula for Spearman's rank order coefficient correlation is given below:

$\mathrm{rs}=1-6 \sum \mathrm{d}^{2}$

$\mathrm{N}\left(\mathrm{N}^{2}-1\right)$

Where $\mathrm{N}=$ number of respondents

$\sum \mathrm{d}^{2}=$ sum of the squared differences in the mean of the two variables. 
* Statistical Testing of Hypotheses

\section{Results}

\section{- Hypothesis one Testing}

H0 $0_{1}$ : There is no significant link between supervisor integrity and property deviance behaviour of oil firms in Port Harcourt.

Table I: Correlation Analysis on the Link between Supervisor Integrity and Property Deviance Behaviour.

\begin{tabular}{|l|l|l|r|r|}
\hline \multicolumn{5}{|c|}{ Correlations } \\
\hline \multirow{3}{*}{ Spearman's rho } & Integrity & Correlation Coefficient & Integrity & Property Deviance \\
\cline { 3 - 5 } & & Sig.(2-tailed) & 1.000 & $.398^{* *}$ \\
\cline { 3 - 5 } & $\mathrm{N}$ &. & .000 \\
\cline { 2 - 5 } & Property Deviance & Correlation Coefficient & $.398^{* *}$ & 198 \\
\cline { 3 - 5 } & & Sig.(2-tailed) & .000 & 198 \\
\cline { 3 - 5 } & $\mathrm{N}$ & 1900 \\
\hline
\end{tabular}

The tested hypothesis in table 1 shows that supervisor integrity correlates with property deviance behaviour at $(.398 * *)$ when the P-value is $.000<0.05$ indicating a weak positive link between the two variables. Thus, we rejected the null hypotheses.

\section{- Hypothesis Two Testing}

$\mathrm{Ho}_{2}$ : There is no Significant Link between Supervisor Integrity and Personal Aggression Behaviour of Oil Firms in Port Harcourt.

Table II: Correlations on the Link between Supervisor Integrity and Personal Aggression

\begin{tabular}{|c|c|c|c|c|}
\hline \multicolumn{5}{|c|}{ Correlations } \\
\hline & & & Integrity & Personal Aggression \\
\hline \multirow{6}{*}{ Spearman's rho } & \multirow{3}{*}{ Integrity } & Correlation Coefficient & 1.000 & $.540^{* * 4}$ \\
\hline & & Sig.(2-tailed) & & .000 \\
\hline & & $\mathrm{N}$ & 198 & 198 \\
\hline & \multirow[t]{3}{*}{ Personal Aggression } & Correlation Coefficient & $.540^{* *}$ & 1.000 \\
\hline & & Sig.(2-tailed) & .000 & \\
\hline & & $\mathrm{N}$ & 198 & 198 \\
\hline
\end{tabular}

In table II: hypotheses result reveals that supervisor integrity correlates with personal aggression at $(.540 * *)$ when $\mathrm{P}$-value is $.000<0.05$. This showed a moderate and positive link, and so the null hypotheses earlier stated was rejected.

\section{- Hypothesis Three Testing}

Ho $:$ Corporate culture will not moderate the link between supervisor trust and counterproductive work behaviour in oil firms in Port Harcourt.

Table III: Partial correlation analysis conducted on corporate culture

\begin{tabular}{|c|c|c|c|c|c|}
\hline \multicolumn{6}{|c|}{ Correlations } \\
\hline \multicolumn{3}{|c|}{ Control Variables } & \multirow{2}{*}{$\begin{array}{r}\begin{array}{c}\text { Superviso } \\
\text { r trust }\end{array} \\
1.000\end{array}$} & \multirow{2}{*}{$\begin{array}{r}\begin{array}{c}\text { Counter } \\
\text { productive } \\
\text { Work behaviour }\end{array} \\
.329\end{array}$} & \multirow{2}{*}{$\begin{array}{r}\begin{array}{c}\text { Corporate } \\
\text { Culture }\end{array} \\
.675\end{array}$} \\
\hline \multirow[t]{9}{*}{-none- ${ }^{\mathrm{a}}$} & \multirow[t]{3}{*}{ Supervisor trust } & Correlation & & & \\
\hline & & Significance (2-tailed) & . & .000 & .000 \\
\hline & & Df & 0 & 198 & 198 \\
\hline & \multirow{3}{*}{$\begin{array}{l}\text { Counter productive Work } \\
\text { behaviour }\end{array}$} & Correlation & .329 & 1.000 & .634 \\
\hline & & Significance (2-tailed) & .000 & . & .000 \\
\hline & & Df & 198 & 0 & 198 \\
\hline & \multirow[t]{3}{*}{ Corporate Culture } & Correlation & .675 & .634 & 1.000 \\
\hline & & Significance (2-tailed) & .000 & .000 & . \\
\hline & & Df & 198 & 198 & 0 \\
\hline \multirow{6}{*}{$\begin{array}{l}\text { Corporate } \\
\text { Culture }\end{array}$} & \multirow[t]{3}{*}{ Supervisor trust } & Correlation & 1.000 & .644 & \\
\hline & & Significance (2-tailed) & . & .000 & \\
\hline & & Df & 0 & 197 & \\
\hline & \multirow{3}{*}{$\begin{array}{l}\text { Counter productive Work } \\
\text { behaviour }\end{array}$} & Correlation & .644 & 1.000 & \\
\hline & & Significance (2-tailed) & .000 & . & \\
\hline & & Df & 197 & 0 & \\
\hline
\end{tabular}


The result obtained indicated that supervisor trust and counterproductive work behaviour correlates at $(.329 * *)$ when P-value is $.000<0.05$. This showed that there is a weak-positive link. We further observed that the moderating influence which corporate culture has on supervisor trust and counterproductive work behaviour is at $\mathrm{r}=.675$, indicating a strong moderation.

\section{Summary of Results}

For a better understanding of the tested hypotheses, table 4.7 below presented a detailed summary of the tested hypotheses.

Table IV: summary of Hypotheses Testing Results .

\begin{tabular}{|l|l|l|l|l|}
\hline TESTED HYPOTHESES & $\begin{array}{l}\text { CORRELAT } \\
\text { IONS }\end{array}$ & P-VALUE RESULTS & $\begin{array}{l}\text { INTERPRETATIO } \\
\text { N }\end{array}$ & DECISION \\
\hline Supervisor integrity/property deviance & .398 & value.000<0.05 & Weak-link & Rejected-Ho \\
\hline Supervisor integrity/personal aggression & .540 & value. $000<0.05$ & Moderate-link & Rejected-Ho \\
\hline $\begin{array}{l}\text { Supervisor trust/counterproductive work behaviour } \\
\text { /corporate culture }\end{array}$ & .675 & value. $000<0.05$ & Strong-link & Rejected-Ho \\
\hline
\end{tabular}

The summarized results above showed that all the variables were positively correlated and so the null hypotheses were rejected.

\section{Supervisor Integrity and Property Deviance Behaviour}

\section{Discussion Of Findings}

The aim of hypothesis one, was to ascertain the influence integrity (fairness in judgement, consistency, promise fulfilment, etc) has over property deviance behaviour. From the spearman's rank order computation (rho $=.398 \mathrm{P}>0.05)$ which showed that a positive and significant link existed between integrity (Fairness in judgement, consistency, promise fulfilment, etc) and property deviance behaviour (sabotaging equipment, accepting kickbacks, etc) of oil firms in Port Harcourt. The finding was supported by the works of Tan \& Lim, (2009); Burke, Sims, Lazzara \& Salas, (2007). who asserted that trust is rated higher in a worker when he is perceived to be more honourable because the end result of their actions will turn-up to be a positive behaviour which includes consistency in the job, honesty, fairness in judgment, etc. This means that supervisor integrity will certainly reduce property deviance behavior of oil firms in Port Harcourt.

\section{Supervisor Integrity and Personal Aggression Behaviour}

The purpose of hypothesis two was to ascertain the influence integrity (fairness in judgment, consistency, promise fulfilment, etc) has over personal aggression behaviour (sexual harassment, verbal abuse, etc). from the spearman's rank order computation The finding was supported by the works of Tan \& Lim, (2009); Burke, Sims, Lazzara \& Salas, (2007) who asserted that trust is rated higher in a worker when he is perceived to be more honourable because the end result of their actions will turn-up to be a positive behaviour which includes consistency in the job, honesty, fairness in judgment, etc They further encouraged leaders to be honourable so that the followers will reduce the counterproductive behaviours in the workplace. Trust has been identified as a problem solver which brings cooperation, among the organizational members (Zand 1992; Axelrod, 1994; Mayer \& Davis 1999) which means that indeed supervisor integrity has the power to influenced personal aggression behaviour positively.

\section{Moderating Role of Corporate Culture on Supervisor Trust and Counterproductive Work Behaviour}

Hypothesis three is the moderating factor whose purpose is to discover the directing part of corporate culture on manager trust and counterproductive work conduct in oil firms in Port Harcourt. The moderating variable (corporate culture) was found to positively influence the relationship between supervisor trust and counterproductive work conduct. From the partial correlation result obtained, it implies $(.675 \mathrm{P}>0.05)$ which demonstrated a solid and positive directing impact on the relationship between supervisor trust and counterproductive work behaviour of oil firms in Port Harcourt. The work of Stoner, Freeman \& Gilbert (2007) agreed with this result when they stated that corporate culture fills in as a manual for a day by day conduct and basic leadership in the work environment, coordinating the worker and customers toward accomplishing the objective of the association. This suggests association that disregards culture can't make due in the dynamic condition. The supervisor educates the subordinate the characteristics of an association's way of life which is later embraced by the representatives as their approach to incorporate regard of seniors, correspondence stream, and so forth. 


\section{Recommendations}

Answering from the discussion of findings the following recommendations were made:

1. In order to reduce or eradicate property deviance behaviour in the subordinates, we recommend that the supervisors/managers should be fare in judgment, honest and consistent in order to influence their subjects towards positive behaviour in the workplace.

2. Management of oil firms should practice and encourage their supervisors/ managers to have integrity in order to reduce their rate of personal aggression behaviour (verbal abuse, sexual abuse, etc). This has a way of boosting the image of the company.

3. It was also revealed that culture has a great role to play in the life style of employees and so i recommend that all the managers/ supervisors should inculcate the culture of their company and force it on the subordinate. When the supervisor and the subordinates embrace the company culture, employees will be effective in their job performance and the counterproductive behaviours will be eradicated.

\section{Conclusion}

The study specific conclusion was summarized as follows:

- Base on the findings, the study conclude that supervisor trust has positive influence on property deviance and personal aggression behaviours in the oil firms.

- Furthermore, we conclude that cooperate culture has a strong-positive moderating factor that established the relationship between supervisor trust and counterproductive work behaviour of oil firms in Port Harcourt.

\section{Implications of Study}

All the findings has some implications which are revealed in the theories, some are applied to the managers and future researchers as we observed further.

\section{- Theoretical Implications}

In order to increase organisational effectiveness, Mcknight \& Chervany (1996) asserts that trust is a vital tool that aides the increase of organisational effectiveness. It also influences organisational processes such as communication, cooperation and information sharing (Savolainen, Hakkinen \& Powell, 2011; Mayer \& Davis, 1999). This implies that no organisation can progress and compete with others favourably when there is distrust among its employees.

\section{- Managerial Implication}

This study is significant to managers who are looking forward to achieving their set goals. Burke, Simms, Lazzara \& Silas (2007) asserts that when leaders are perceived as honourable that the followers engage into more risky behaviours. This implies that managers must have attributes like:

- Integrity which is shown in his honesty, fair judgment, etc. it makes a manager or supervisor to have influence over the subordinates in order to increase the subordinate job performance which is geared towards goal achievement (Mayer, Davis \& Schoorman 1995).

\section{- Implications for Research Practice}

This study has been found to be of great importance to the researchers, which implies that it will help them to obtain more facts as they go for further research in any organisation.

\section{Contribution to Knowledge}

1. The result of the findings serves as a very strong tool for managers of different organizations order than the studied area to develop an enabling environment of fair and equitable principles that will influence subordinate behaviour positively.

2. The knowledge of this result will help the government to make policies that will encourage the improvement of leader's skills in order to reduce negative behaviours in the workplace. When this is done, they will begin to have accurate annual reports ranging from financial report to any other official reports.

3. Corporate culture has also been known to have a great influence over the behaviour of employees and the overall organizational performance which invariably promotes positive behaviours. The knowledge of this will help the owners of any establishment to encourage its employees to embrace the corporate culture.

\section{References}

[1] Anyanwu, A. (2000). Research Methodology in Business and Social Sciences Imo State Canun Publishers Nig. Ltd. Owerri.

[2] Appelbaum, S.H., Laconi G.D. \& Matousek, A. (2007). Positive \& Negative deviance workplace behaviour: Causes, impact and solutions. Corporate government, 7 (5), 586-598.

[3] Axelrod, R. (1994). The Evolution of Cooperation. New York: Basic Books.

[4] Baridam, D.(2001).Research method in administrative sciences. Port Harcourt: Sherbrook Associates.

[5] Bennett, R.J \& Robinson, S.L. (2000).Development of a measure of workplace deviance. Journal of applied psychology. 85(3), 349360 .

[6] Burke, C.S., Sims, D.E., Lazzara, E. H. \& Salas, E. (2007). Trust in Leadership: A multi-level Review and integration. The leadership Quarterly 18(6), 606-632. http://dx.doi.org/10.1016/j.leaque.2007 
[7] Conger, J.A (1990).The Dark Side of Leadership, Organisational Dynamics, 19, (2) pp. 44-55.

[8] Costa, A. C \& Bijlsma-Frankema,(2007). 'Trust and Control Interrelations: New Perspectives on trust Control Nexus'. Group \& Organisation Management, 32, (4), pp.392-406.

[9] Crombach, L. J. \& Meehl, P.E. (1955). Construct Validity in psychological Test. 52, (4).

[10] Curral, S.C. \& Judge, T.A. (1995).Measuring trust between organisational boundary role persons. Organisational behaviour and Human Decision Processes, 64, 151-170.

[11] Danserean, F., Graen, G. \& Haga, W.J. (1975).A vertical dyad approach to leadership within formal organizations. Organisational behaviour and human performance, 13, $46-78$.

[12] Dirks, K. T., \& Ferrin, D. L. (2002). Trust in leadership: Meta-analytic findings and implications for research and practice, Journal of applied psychology, 87 (7), pp. 611-628.

[13] Dirks, K.T. (2006). Three fundamental questions regarding trust in leaders. In Bachmann, R. and Zaheer, A. (ed.), Hand book of Trust Research. (pp. 15-28). Northhampton, USA: Edward Elgar Publishing

[14] Eltikan, I.; Musa, S . A \& Alkassim, 2016. Comparison of convenience sampling and purposive sampling. American Journal of Theoretical and Applied statistics, 5 (1), 1-4

[15] Findikli, M.A. ; Gulden, A. \& Semercioz, F. (2010). Subordinate trust in supervisor and organisation: Effects on subordinate perceptions of psychological empowerment. International Journal of Business and management studies. 2, (1).

[16] Fox, S. \& Spector, P.E. (2011).Counterproductive work behaviour our Checklist CWB-C (32-items).German and English version.

[17] Fox, S., Spector, P.E. \& Miles, D. (2001).Counterproductive Work behaviour (CWB) in response to Job Stressors and organisational: Some mediator and Moderator test for Autonomy and Emotions. Journal of Vocational Behaviour 59, 291-309. Doi:10,1006/jvbe.2001.1803. http://www.idealibrary.com

[18] Gerstner, C.R. \& Day, D. V. (1997). Meta-analytic review of leader-member exchange theory: correlates and construct issues. Journal of applied psychology 82, 827-844,

[19] Gomez, C. \& Rosen, B. (2001)."The leader-member exchange a link between managerial Trust and employee empowerment", group \& organization management, 26 (1), 53-69.

[20] Hart, J. (2015).Trust in Supervisor and Organisational Citizenship Behaviour in Private Hospitals. Uniport, Port Harcourt, Rivers State.

[21] Lewicki, R.J., Tomlinson, E.C. \& Gillespie, N. (2006). Models of interpersonal trust development: Theoretical approaches, empirical evidence, and future directions. Journal of management, 32 (6), 991-1022.

[22] Lies, R., Nahrgang, J. D .\& Morgeson, F.P. (2007). Leader-member exchange and citizenship behaviours: A meta-analysis Journal of applied psychology Vol. 92, No.1 269-2

[23] Maanen, J. V.(2014).The Effect of Trustworthiness on the intention to perform OCB. http://www.purl.utwente.nl/essays/65863.

[24] Mayer, R.C, Davis, J.H. \& Schoorman, F. D. (1995).An integration model of organisational trust, Academy of management Review 20(5), 709-734.

[25] Mayer, R.C. \& Davis, J.H. (1999).The effect of the performance appraisal system on Trust for Management: A field quasiexperiment Journal of Applied Psychology, 84 (3), pp. 123-136.

[26] Mcknight, D. H. \& Chervany, N.L. (1996).Meaning of Trust, University of Minnesota MIS Research Center working paper series, WP 96-04,http://misrc.umn.edu/wpaper/Working Papers/9604.pdf

[27] Nachmias, C.F. \& Nachmias, D.(2009). Research Methods in the Social Sciences, $5^{\text {th }}$ ed. London: Holder Education.

[28] Ogolo, M.B. (1996). Student guide to writing project, proposal and research. Port Harcourt: City Creek Publisher.

[29] Paul, O. M. (2015).Deviant Behaviour and Firm Growth in Manufacturing Firms in Port Harcourt: MSC Thesis, University of Port Harcourt, Port Harcourt.

[30] Premium times (2016). Pipeline Sabotage: NNPC shuts down. Port Harcourt, Kaduna refineries. http://www.premiumtimesng.com/business/business news/197075-pipeline-sabotage-nnpc-shuts-port-harcourt-kadunarefinaries.htm/ Psychological test, 52, (4).

[31] Robinson, S. \& Bennett, R. (1995). A typology of deviant workplace behaviours: A multi-dimensional scaling study, Academy of management journal, 38 (2) pp. 555-572 http://dx doi.org 10.2307

[32] Savolainen, T., Hakkinen, S. \& Powell, C. (2011). Trusted to lead: Trustworthiness and its impact on Leadership. https:time review.Ca/article/429.

[33] Semercioz,F., Hassan, M. \& Aldemir, Z.(2011). An empirical study on the role of interpersonal trust and institutional trust in organisational innovativeness. International Business resources, 4(2).

[34] Shell International Limited (2014). Shell General Business principles. Responsibilities sgbp-english.

[35] Tan H. \& Lim, A. (2009). Trust in Co-workers and trust in organisations. The Journal of psychology.. 143,(1) pp.45-66. 92, 4, 909927. $92,4,909-927$.

[36] Wikipedia,(2017). Nigerian Gas Association. https//.m.wikipedia.org/wiki/Nigerianl-Gas-Association

[37] Zand, D.E.(1972). Trust and managerial problem solving. Administrative science quarterly 17 (2) ; 229-39.

\section{QUESTIONNAIRE SECTION A}

\section{Demographic Data}

Instruction: Please kindly indicate the appropriate option in your opinion by ticking () in the box provided in each of the questions below:

1. Name of your company:

2. Position held.

3. Sex: Male

4. Age: $20-30$ years 51 years and above

5. Marital status: Single

6. Academic Qualification: $\mathrm{HND}$ BSC $\square$ Masters Professional qualification Others specify.

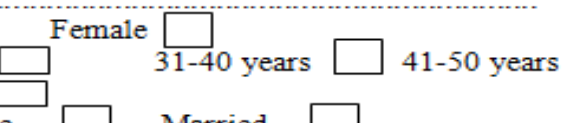

7. How long have you been with the company

$1-5$ years

11 - 15 years $16-20$ years

21 years and above 


\section{Supervisor Trust (Dependent variable)}

Please kindly use the keys below to answer the questions.

Keys $\quad=1=$ Strongly Disagree $(\mathrm{SD}), 2=$ Disagree $(D A), 3=\operatorname{Neutral}(\mathrm{N}), 4=$ Agree $(\mathrm{A}) .5=$ Strongly Agree (SA)

Supervisor Trust

\begin{tabular}{|c|c|c|c|c|c|c|}
\hline $\mathbf{S} / \mathbf{N}$ & QUESTIONS & $\begin{array}{l}\text { SD } \\
1 \\
\end{array}$ & $\begin{array}{l}\text { DA } \\
2\end{array}$ & $\begin{array}{l}\mathbf{N} \\
\mathbf{3}\end{array}$ & $\begin{array}{l}A \\
4\end{array}$ & $\begin{array}{l}\mathbf{S A} \\
5 \\
\end{array}$ \\
\hline & Integrity & & & & & \\
\hline 1 & My supervisor is straight forward in judgment always. & & & & & \\
\hline 2 & He sticks to whatever he says & & & & & \\
\hline
\end{tabular}

Counterproductive Work behaviour (Dependent Variable)

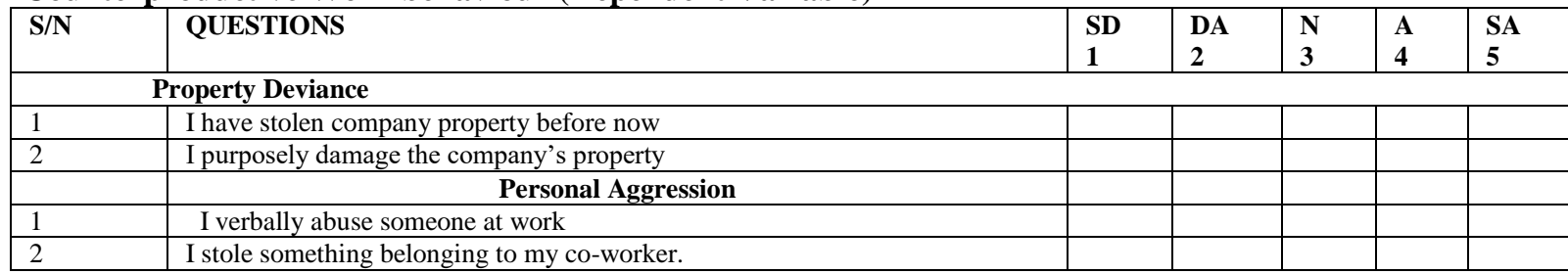

\section{Corporate Culture}

\begin{tabular}{|c|c|c|c|c|c|c|}
\hline $\mathbf{S} / \mathbf{N}$ & QUESTIONS & $\begin{array}{l}\text { SD } \\
1\end{array}$ & $\begin{array}{l}\text { DA } \\
2\end{array}$ & $\begin{array}{l}\mathbf{N} \\
\mathbf{3}\end{array}$ & $\begin{array}{l}A \\
4\end{array}$ & $\begin{array}{l}\text { SA } \\
5\end{array}$ \\
\hline 1 & The way of doing things in the company depends on the supervisor instructions & & & & & \\
\hline 2 & Employees' comments and recommendations often lead to changes in the company & & & & & \\
\hline
\end{tabular}

